\title{
Top Executives' Ability and Earnings Quality: Evidence from the Chinese Capital Markets
}

\author{
Han $\mathrm{Li}^{1}$ \\ ${ }^{1}$ Sydney Institute of Language \& Commerce, Shanghai University, Shanghai, China \\ Correspondence: Han Li, Sydney Institute of Language \& Commerce, Shanghai University, 20 Chengzhong Road, \\ JiaDing District, Shanghai 201800, China. Tel: 86-21-6998-0028 ext. 53101. E-mail: lihan@shu.edu.cn
}

Received: February 5, 2014

Accepted: February 23, 2014

Online Published: March 31, 2014

doi:10.5430/ijfr.v5n2p79

URL: http://dx.doi.org/10.5430/ijfr.v5n2p79

\begin{abstract}
Earnings Quality can be influenced by the industry, the firm and the manager. Prior researches focus more on the industry and the firm. Currently, to measure the relationship between earnings quality and the managerial ability is interested by scholars. This paper tries to analyze the listed firms in Chinese Capital Markets and to measure the managerial ability in these firms by applying data envelopment analysis (DEA) and regression models. In this research, violation against accounting standards in financial reporting and DACC (Discretionary Accruals) are used to measure the earnings management. With the analysis, I find that earnings quality of these public firms is highly related with managerial ability in Chinese listed companies.
\end{abstract}

Keywords: managerial ability, earnings quality, Chinese listed firms, data envelopment analysis, earnings management

\section{Introduction}

The research examines the relation between managerial ability and earnings quality after analyzing the listed firms in the Chinese capital markets. The results anticipate that higher ability managers in Chinese firms are more understandable of their industry and better in decision making and more accurate in forecasting and therefore, to get higher quality earnings. Prior archival literature in the research of earnings quality provides mixed evidence on this relation and also mainly focused on firm-specific characteristics. For example, firm size has been identified as a potentially important variable for earnings management. Large size firms normally have lower nondiscretionary accruals because they have lower growth prospects (Ecker et al. 2011 and Dechow et al. 2012). However, how the manager-specific factors influence the earnings quality is still not very clear. Some scholars had already made some contributions in this field. For instance, Bertrand and Schoar (2003) advocate that manager fixed effects matter for a wide range of corporate decisions. This finding appears to indicate general differences in "style" across managers exist. Francis et al. (2008) document that more reputed CEOs has negative relation with the firm's earning quality. Malmendier and Tate (2009) demonstrate that superstar CEOs are more likely to influence reported performance by earning management in order to meet the market's higher expectation on these superstar CEOs. Demerjian et al. (2012) suggests that more knowledgeable managers, leading to better judgments and estimates as reflected in accrual decisions, report higher quality earnings. This paper wishes to make further contribution in investing the manager-specific aspects on earnings quality.

This research provides a broad overview to examine the relation between managerial ability and earnings quality with the analysis of listed firms in Chinese stock markets. The method for evaluating the managerial ability is mainly based on the one advocated by Demerjian et al (2012). Demerjian et al (2012) has applied the DEA (Data Envelopment Analysis) for measuring the output's efficiency based on some specific inputs. The modified DEA scores (MgrlScore) to measure the firm's efficiency is the indicator of managerial ability. This MgrlScore makes us to better differentiate the manager-specific effects from the firm-specific effects and to supply an ordinal ranking of quality for a large sample firms in Chinese stock markets. While, regards to the measures of earnings quality, this paper considers the violation against accounting standards of financial reporting standards and the DACC (Discretionary Accruals).

With the analysis of a large sample investigated from the Chinese listed firms for the sample period of 2007 - 2012 , this paper finds that generally high ability managers are more likely to report lower violation against financial 
reporting standards and lower DACC(Discretionary Accruals), in other words, higher managerial ability in top executives always accompanies with lower earnings management. Therefore, this finding suggests that in the listed firms of China, higher ability managers are positively associated with higher quality earnings.

The rest of the paper proceeds as follows. Section 2 provides a review of literature and makes the hypothesis development. In Section 3, it describes the research design and data analysis. Section 4 presents results of empirical analysis. Section 5 summarizes the conclusions of this study.

\section{Literature Review and Hypothesis Development}

Earnings quality is an important indicator for accurately assessing the value of a company. In applying for valuation models, earnings are always considered the key inputs whether we use the DCF (Discounted Cash Flow) model or AE (Abnormal Earning) model. Furthermore, firms with good earnings quality cause to have lower costs of capital (e.g. Francis et al. 2004). Dechow et al. (2010) define earnings quality as follows: "Higher quality earnings provide more information about the features of a firm's financial performance that are relevant to a specific decision made by a specific decision-maker". Furthermore, Demerjian et al. (2013) believes that high-quality earnings can accurately reflect companies' operating performance.

Although many papers have examined the factors that attribute to the earnings quality, there are few researches focus on manager specific effects. Specially, very few studies have tried to investigate whether executives' characteristics affect information processing. This causes the psychological and social processes by which executive profiles become the strategic choices still remain largely a mystery and a magic decision process (Hambrick 2007).

The neoclassical view of the firm implicitly assumes that managers, especially top managers, are homogenous and selfless inputs into the management process. In other words, managers are perfect substitutes for one another. The performance of the firm would not be influenced by the specific style of different managers. Therefore, under this thought, two firms which confront similar economic circumstances and market conditions will make similar decisions, whether or not these firms have similar ability management teams. If this were true, managers' personal characteristics would not matter for the earnings quality.

Contrary to the neoclassical views, upper echelons theory (Hambrick and Mason 1984) views the organization's top managers as the dominant factor in shaping the organizational outcomes - both strategies and effectiveness which reflect the values and cognitive bases of powerful top executives in the organization. Moreover, recent studies have also emphasized on individual managers for a series of corporate activities. Hambrick (2007) argues that executives, the powerful actors, behave on the basis of their personalized interpretations of the business situation they deal with, and these personalized construals are a function of their demographic characteristics and values. Bertrand and Schoar (2003) believes that management "styles" which significantly related to manager fixed effects matter for explaining why managers may behave so differently in apparently similar economic situations. A large extent of the heterogeneity in investment, financial, and organizational decisions of firms can be answered by the different of manager fixed effects.

Following this stream of literature, there are also other proxies of manager fixed effects. Top executives play unique and economically significant influence on their firm's voluntary disclosures. While their unique disclosure styles are associated with top managers' personal demographic characteristics (e.g. functional career, age cohort, military experience, M.B.A. education) (Bamber et al. 2010, Hambrick and Mason 1984, Finkelstein and Hambrick1996). Ge et al. (2011) finds that a portion of the variation in accounting choices could be attributable to executives - level managerial characteristics. Malmendier and Tate (2005) argue managerial overconfidence can explain for corporate investment distortions. Overconfidence even helps CEOs exploit innovative growth opportunities (Hirshleifer et al. 2012).

The following literatures relate to the topics that managerial characteristics matter for the earning quality. Superstar CEOs, higher frequency reported by the public media, subsequently underperform, both relative to their previous performance and comparative to a matched sample of non-superstar CEOs. The possibility of earnings management increases after CEOs achieving superstar status, especially in the weak corporate governance firms (Malmendier and Tate 2009). Francis et al. (2008) document a negative relation between CEO reputation and earnings quality (Note 1). Brochet et al. (2001) investigate executive turnovers and changes in guidance might be jointly determined by contemporaneous events that are not captured by firm - and industry - specific determinants of guidance issuance. Managers also contribute to the provision of earnings guidance by assessing the relation between top executive turnovers and guidance. They find newly appointed externally hired CEOs increase the likelihood of providing guidance among firms that did not issue guidance historically. 
Unlike the above managerial characteristics. This research is more in the vein of Demerjian et al. (2013) in which they examine the relation between managerial ability and earnings quality and find earnings quality is positively related with managerial ability. Demerjian et al. (2012) developed a method to evaluate the managerial ability (MgrlScore) by distinguishing the manager specific effects with the firm specific effects after they used data envelopment analysis (DEA) to estimate firm efficiency within industries, comparing the sales relative to the costs and assets used by the firm: Cost of Goods Sold, Selling and Administrative Expenses, Net PP\&E, Net Operating Leases, Net Research and Development, Purchased Goodwill, and Other Intangible Assets. They also select four measures of earnings quality, such as, earnings restatements, earning persistence, errors in the bad debt provision, and the accruals realized as cash flows. Demerjian et al. (2013) conclude that a negative relation between managerial ability and restatements, higher quality managerial ability with higher persistence of the accrual component of earnings, more able managers forming better estimates of bad debt provisions and the more capable the manager, the better ability to estimate accruals. Therefore, it is clear that higher quality managers are associated with higher quality earnings.

More able managers are more knowledgeable about the change of macroeconomic trend, the development of the industry and the operation of the firm as well as to be better able to synthesize information into future estimation. In more details, I believe that high-ability managers can be more accurate than low-ability managers in compliance with the financial reporting standards. Therefore, I expect that a more able manager to report higher quality earnings.

\section{H1: It is positive relationship between managerial ability and earnings quality.}

\section{Research Design and Data and Variable Definitions}

\subsection{Managerial Ability Measurement}

In order to measure managerial ability in a firm, the data envelopment analysis (DEA) is used to determine the firm efficiency and the managerial ability factor is derived from the firm efficiency. The method is developed by Demerjian et al. (2012).

DEA is a statistical technique to measure the relative efficiency of separable entities which are named as "decision-making units"(DMUs) by applying multiple inputs and outputs. The inputs could be labor, capital, technique and etc. While, the outputs could be revenue, income. DEA forms an efficient frontier of possible production points to maximize a ratio of outputs relative to inputs. DMUs are just at the frontier on which maximum output levels are matched with given input levels. However, the points under the efficient frontier reflect inefficient units (Cooper, et al. 2000). DEA efficiency is defined as follows:

$$
\frac{\sum_{i=1}^{S} u_{i} y_{i k}}{\sum_{j=1}^{m} v_{j} x_{j k}} \quad \mathrm{k}=1, \ldots, \mathrm{n}
$$

In this equation, $s$ outputs, $m$ inputs and $n$ DMUs are included. $\mathrm{u}_{i}$ and $\mathrm{v}_{j}$ are the weights on outputs and inputs respectively. $\mathrm{y}_{i k}$ and $\mathrm{x}_{j k}$ are the quantities of each output and input separately. In this research, there is only one output which is sales revenue; six inputs exist as follows: (i) Cost of Goods Sold; (ii) Selling, General, and Administrative Expenses (SG\&A); (iii) Plant, Property and Equipment (PPE); (iv) Net R\&D; (v) Purchased Goodwill; and (vi) Other Intangible Assets. The following optimization equation is solved:

$$
\max _{v} \theta=\frac{\text { Sales }}{v_{1} \operatorname{CoGS}+v_{2} S G \& A+v_{3} P P E+v_{4} R \& D+v_{5} \text { Goodwill }+v_{6} \text { OtherIntan }}
$$

The accounting standards changed largely since 2007 in China. In order to fit for the definition of accounting of Chinese Accounting Standards, this research combine the six inputs together as total inputs. The concise equation is as follows:

$$
\max _{v} \theta=\frac{\text { Sales }}{\text { Cost }}
$$

In the process of analyzing DEA efficiency, the DEAP version 2.1 written by Tim Coelli is used (Note 2). The DEA analysis is based on standard CRS model with DEA Multi-Stage. The DEA efficiency analysis produces $\theta$ which ranges from 0 to 1 . For the value equals to 1 , it reflects the most efficient and observations with efficiency measures fall on the efficient frontier; for the value which is less than 1, observations with efficiency measures fall below the efficient frontier.

The efficiency measure $\theta$ is influenced by the firm and the manager which is similar as previous research results that measures such as media coverage and historical returns are difficult to attribute solely to the manager or manager 
fixed effects (Francis et al. 2008). The research follows the method advocated by Demerjian et al. (2012) that the firm efficiency $\theta$ can be divided into several key firm-specific characteristics which would be increase or reduce the management's performance, such as total assets, positive free cash flow, firm age, foreign currency indicator and the residual factor (note 3 ). Taking the following Tobit regression model by industry:

$$
\begin{gathered}
\text { Firm Efficiency }=\alpha_{0}+\alpha_{1} \operatorname{Ln}(\text { Total Assets })+\alpha_{2} \text { Positive Free Cash Flow }+\alpha_{4} \operatorname{Ln}(\text { Age }) \\
+\alpha_{5} \text { Foreign Currency Indicator }+ \text { Year Indicators } \\
+\varepsilon
\end{gathered}
$$

The resulting residual $\varepsilon$ which attribute to manager specific effect is the measure of managerial ability (MgrlScore).

\subsection{Earnings Quality Measurement}

For measures of earnings quality, this paper consider the following measures of earnings quality: (1) the violations against accounting standards in financial reporting and (2) Based on the research by Dechow et al (1995), Jones et al (1991) and Lu (1999), Discretionary accruals that are the difference between total accruals and non-discretionary accruals can be used to measure earnings management.

First, violations against accounting standards in financial reporting based on the historical record in CSMAR database. If there are violations records in the sample year, the variable assumes to be 1 . Otherwise, it would be 0 .

Second, Jones et al (1991) indicated that the accruals would be increased with the growth of sale revenues and fixed assets. Non-Discretionary Accruals (NDACC) are the function of changes of sales revenues and size of PPE (Property, Plant and Equipment).The DACC(Discretionary Accruals) can be found by the difference between real accrual and Non-Discretionary Accruals. Jones's model is as follows:

$$
\begin{gathered}
\frac{T A C C_{i t}}{A_{i t-1}}=\alpha_{i}\left[\frac{1}{A_{i t-1}}\right]+\beta_{1 i}\left[\frac{\Delta R E V_{i t}}{A_{i t-1}}\right]+\beta_{2 i}\left[\frac{P P E_{i t}}{A_{i t-1}}\right]+\varepsilon \\
\frac{N D A C C_{i t}}{A_{i t-1}}=\alpha_{i}^{\prime}\left[\frac{1}{A_{i t-1}}\right]+\beta_{1 i}^{\prime}\left[\frac{\Delta R E V_{i t}}{A_{i t-1}}\right]+\beta_{2 i}^{\prime}\left[\frac{P P E_{i t}}{A_{i t-1}}\right]+\varepsilon \\
D A C C_{i t}=\frac{T A C C_{i t}}{A_{i t-1}}-N D A C C_{i t}
\end{gathered}
$$

In which:

TACC $_{i t}$ : Total accruals in $\mathrm{t}$ year for company $\mathrm{i}$

$\triangle R E V_{i t}$ : Revenues change in $\mathrm{t}$ year for company $\mathrm{i}$

$P P E_{i t}$ : Property, Plant and Equipment in t year for company $\mathrm{i}$

$N D A C C_{i t}:$ Non - Discretionary Accruals in t year for company $\mathrm{i}$

$D A C C_{i t}$ : Discretionary Accruals in t year for company $\mathrm{i}$

Dechow et al (1995) modified Jones's models because Jones' models can overestimate the non-discretionary accruals due to the reasons that the receivable can be resulted from earnings manipulation. Dechow et al (1995) modified Jones model as follows:

Dechow et al (1995) modified the Jones

$$
\begin{gathered}
\frac{T A C C_{i t}}{A_{i t-1}}=\alpha_{i}\left[\frac{1}{A_{i t-1}}\right]+\beta_{1 i}\left[\frac{\Delta R E V_{i t}-\Delta R E C_{i t}}{A_{i t-1}}\right]+\beta_{2 i}\left[\frac{P P E_{i t}}{A_{i t-1}}\right]+\varepsilon \\
\frac{N D A C C_{i t}}{A_{i t-1}}=\alpha_{i}^{\prime}\left[\frac{1}{A_{i t-1}}\right]+\beta_{1 i}^{\prime}\left[\frac{\Delta R E V_{i t}-\Delta R E C_{i t}}{A_{i t-1}}\right]+\beta_{2 i}^{\prime}\left[\frac{P P E_{i t}}{A_{i t-1}}\right]+\varepsilon \\
D A C C_{i t}=\frac{T A C C_{i t}}{A_{i t-1}}-N D A C C_{i t}
\end{gathered}
$$

This research is based on Modified Jones Model to find the DACC $C_{i}$. First, equation (4) is used to get $\alpha_{i}, \beta_{1 i}, \beta_{2 i}$. Then $\alpha_{i}^{\prime}, \beta_{1 i}^{\prime}, \beta_{i}^{\prime}$ in equation (5) can be valued separately by $\alpha_{i}, \beta_{1 i}, \beta_{2 i}$. The earnings management for company $\mathrm{i}$ in year $\mathrm{t}$ would be $D A C C_{i}$.

\subsection{Sample Collection and Sources of Data}

This paper is to target the public firms listed in Shanghai and Shenzhen A-share stock market. All resources are 
originated from CSMAR database. Because firms in financial industries have different accounting statements compared with other industries' firms, this research deletes the banking, insurance firms and security firms. The $\mathrm{ST} /{ }^{*} \mathrm{ST} / \mathrm{PT}$ firms, B-Share firms and firms without accounting information in China are also deleted. Finally, 5,390 samples are selected in the Chinese stock markets, starting from 2007 to 2012. Related variables are defined in Table 1.

Table 1. Variable definitions

\begin{tabular}{|c|c|c|}
\hline Variables & Description & Explanation \\
\hline \multicolumn{3}{|l|}{ Explained Variables } \\
\hline \multirow[t]{2}{*}{ MgrlScore } & Managerial Ability & Based on the results of DEA analysis \\
\hline & & Residual $\varepsilon$ from the regression \\
\hline Explainable Variables & Explainable Variables: & \\
\hline \multirow[t]{2}{*}{ Violation } & $\begin{array}{l}\text { Violation against accounting standards in } \\
\text { Financial Reporting }\end{array}$ & $\begin{array}{l}\text { An indicator that would be } 1 \text { if violation exists, } \\
\text { otherwise } 0\end{array}$ \\
\hline & & Based on modified Jones model \\
\hline \multirow[t]{2}{*}{$D A C C$} & Discretionary Accruals & \\
\hline & & $D A C C_{i}=\frac{T A C C_{i}}{A_{i-1}}-N D A C C_{i}$ \\
\hline Control Variables & Control Variables: & \\
\hline FirmSize & Firm Size & The natural $\log$ of Total assets in year $t$ \\
\hline \multirow[t]{2}{*}{ AuditRes } & Audit Results & $\begin{array}{l}\text { An indicator that would be } 1 \text { if the audit result is } \\
\text { clean audit report, otherwise } 0\end{array}$ \\
\hline & & Sales growth change between current's year and \\
\hline \multirow[t]{3}{*}{ SalesGrowth\% } & Percentage Change in Sales Growth & \\
\hline & & 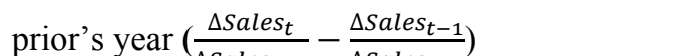 \\
\hline & & $\Delta$ Sales $_{t-1} \quad \Delta$ Salest-2 $_{t}^{\prime}$ \\
\hline OperCycle & Operating Cycle & \\
\hline SdSales & Sales Volatility & Standard Deviation of Sales \\
\hline SdCashFlows & Cash Flows Volatility & Standard Deviation of Cash Flows \\
\hline
\end{tabular}

In order to testify the $\mathrm{H} 1$ : there is positive relationship between the managerial ability and earnings quality.

First, this research tries to measure whether there is significantly negative relationship between the managerial ability of firms and violation of financial reports. To get the above purposes, this paper estimates the following multiple regress based on panel data:

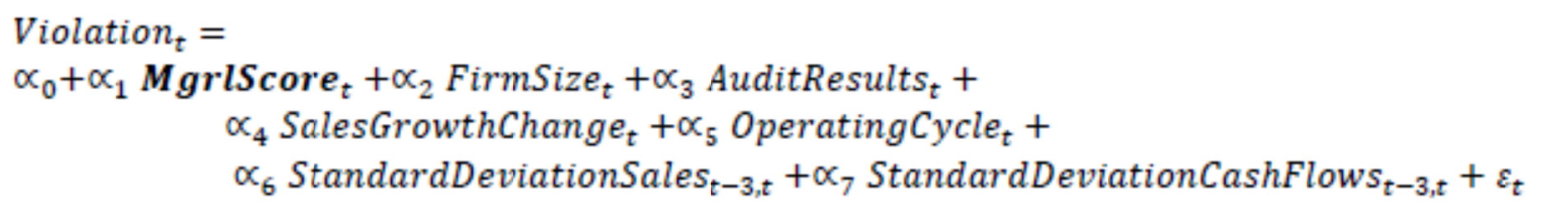

Second, in order to investigate whether there is significantly negative relationship between the managerial ability of firms and DACC (Discretional Accrual), this paper estimates the following multiple regress based on panel data:

$$
\begin{aligned}
& \text { Accruals }_{t}= \\
& \propto_{0}+\propto_{1} \text { MgrlScore }_{t}+\propto_{2} \text { FirmSize }_{t}+\propto_{3} \text { AuditResults }_{t}+ \\
& \propto_{4} \text { SalesGrowthChange } e_{t}+\propto_{5} \text { Operating Cycle }_{t}+ \\
& \propto_{6} \text { StandardDeviationSales }_{t-3, t}+\propto_{7} \text { StandardDeviationCashFlows }_{t-3, t}+\varepsilon_{t}
\end{aligned}
$$

In which:

Accruals, $D A C C_{i}$, are got from the Modified Jones Model. 


\section{Empirical Analysis and Discussing}

\subsection{Descriptive Statistics}

Based on the statistics software STATA, the results of descriptive statistics are including: $\mathrm{n}$, mean, standard deviation, maximum value and minimum value (see Table 2).

Table 2. Descriptive statistics

\begin{tabular}{lrrrrr}
\hline Variable & $\mathrm{N}$ & Mean & Std. Dev. & Min & Max \\
\hline Violation & 5390 & 0.1055659 & 0.3073097 & 0 & 1 \\
DACC & 5329 & $-1.32 \mathrm{E}+19$ & $1.32 \mathrm{E}+20$ & $-2.87 \mathrm{E}+21$ & $3.12 \mathrm{E}+21$ \\
MgrlScore & 5390 & $-4.16 \mathrm{E}-11$ & 0.0911112 & -0.6902314 & 0.6286216 \\
AuditRes & 5390 & 0.9014842 & 0.2980384 & 0 & 1 \\
FirmSize & 5390 & 21.03372 & 0.8706488 & 17.41197 & 24.328 \\
SalesChange & 5357 & -25.45613 & 1842.288 & -134606.4 & 5542.519 \\
SdSales & 4077 & 0.0202516 & 0.0741302 & 0 & 1.822212 \\
OperCycle & 5380 & 5.354358 & 1.175705 & -1.466597 & 17.96971 \\
SdCashFlows & 4077 & 0.012418 & 0.0448716 & 0 & 0.8690128 \\
\hline
\end{tabular}

Sources: CSMAR database.

Based on the descriptive statistics table, the average of MgrlScore is close to 0. Its min value is -0.69 and its max value is 0.63 . These mean the top executives' managerial ability in Chinese listed companies is good.

Table 3. Correlation

\begin{tabular}{|c|c|c|c|c|c|c|c|c|c|}
\hline & Violation & DACC & MgrlScore & AuditRes & FirmSize & SalesChange & SdSales & OperCycle & SdCashFlows \\
\hline Violation & 1 & & & & & & & & \\
\hline$D A C C$ & 0.0096 & 1 & & & & & & & \\
\hline MgrlScore & -0.0265 & -0.0305 & 1 & & & & & & \\
\hline AuditRes & 0.0322 & -0.0184 & -0.075 & 1 & & & & & \\
\hline FirmSize & -0.0397 & -0.1694 & -0.0167 & 0.1536 & 1 & & & & \\
\hline SalesChange & 0.0098 & -0.005 & 0.0103 & -0.0083 & -0.0023 & 1 & & & \\
\hline SdSales & 0.0016 & -0.0278 & -0.0054 & 0.0519 & 0.0984 & 0.0004 & 1 & & \\
\hline OperCycle & 0.0449 & 0.0679 & 0.0187 & -0.1686 & -0.2833 & -0.0111 & -0.1881 & 1 & \\
\hline SdCashFlows & 0.001 & -0.0176 & 0.01 & 0.039 & 0.0759 & 0.0003 & 0.6992 & -0.1363 & 1 \\
\hline
\end{tabular}

Sources: CSMAR database.

Based on the correlation Table 3, it is clear that the variable MgrlScore has negative relationship with Violation and DACC (Discretionary accruals).

\subsection{Regression Analysis}

This research expects that there is negative relation between managerial ability and earnings management.

The paper include each of control variable discuss before in Table 1 . The regression model 7 is to testify the relationship between managerial ability and violation of financial reports. The results are in the Table 4 and documents that negative relation between them exists. The regression model 8 is to measure the relationship between managerial ability and discretional accruals. Its results in the Table 5 express the expected negative relation between managerial ability and discretional accruals.

Therefore, the results of regression analysis support the hypothesis that is managerial ability is related with earnings quality in Chinese stock market. 
Table 4. Managerial ability and violation in financial reporting

\begin{tabular}{lrrr}
\hline Violation & Prediction & Coef & Coef. \\
\hline & & Random Effect & Fixed Effect \\
MgrlScore & - & -0.1188938 & -0.1163272 \\
AuditRes & - & 0.0513476 & 0.0580559 \\
FirmSize & - & -0.0156322 & -0.015308 \\
SalesChange & + & 0.0002235 & 0.0001922 \\
OperCycle & + & 0.0058896 & -0.0054517 \\
SdSales & + & 0.0333099 & 0.0022032 \\
SdCashFlows & + & -0.2383752 & -0.3992302 \\
cons & $?$ & 0.3556013 & 0.406021 \\
\hline
\end{tabular}

Sources: CSMAR database.

Hausman Test (see Table 4) can be evaluated the random and fixed effects on the panel regression analysis. Under the confidence level $95 \%$, due to $\mathrm{P}<0.05$, the null hypothesis based on random effect can be rejected. The results in fixed effect are better than the ones in random effect. The p-value in fixed effect is $0.027<0.05$ under the confidence level $95 \%$. Therefore, the negative relationship between violation against accounting standards and managerial ability (MgrlScore) is statistically confident.

Table 5. Managerial ability and accruals in financial reporting

\begin{tabular}{lrrr}
\hline Accruals & Prediction & Coef. & Coef. \\
\hline & & Random Effect & Fixed Effect \\
MgrlScore & - & $-6.39 \mathrm{E}+19$ & $-7.04 \mathrm{E}+19$ \\
AuditRes & - & $3.15 \mathrm{E}+18$ & $-3.62 \mathrm{E}+18$ \\
FirmSize & - & $-2.69 \mathrm{E}+19$ & $2.03 \mathrm{E}+18$ \\
SalesChange & + & $-5.09 \mathrm{E}+16$ & $-5.58 \mathrm{E}+16$ \\
OperCycle & + & $2.27 \mathrm{E}+18$ & $-4.19 \mathrm{E}+18$ \\
SdSales & + & $-2.87 \mathrm{E}+19$ & $-8.23 \mathrm{E}+19$ \\
SdCashFlows & + & $3.6 \mathrm{E}+18$ & $-1.1 \mathrm{E}+20$ \\
cons & $?$ & $5.39 \mathrm{E}+20$ & $-2.9 \mathrm{E}+19$ \\
\hline
\end{tabular}

Sources: CSMAR database.

Hausman Test (see Table 5) can be evaluated the random and fixed effects on the panel regression analysis. Under the confidence level $95 \%$, due to $\mathrm{P}<0.05$, the null hypothesis based on random effect can be rejected. The results in fixed effect are better than the ones in random effect. The p-value in fixed effect is $0.019<0.05$ under the confidence level 95\%. Therefore, the negative relationship between DACC (Discretionary Accruals) and managerial ability (MgrlScore) is statistically confident.

\section{Conclusions}

This paper tries to analyze the listed firms in Chinese Capital Markets and to measure the managerial ability in these firms by applying data envelopment analysis (DEA) and Tobit regression model. With the analysis, this paper finds that generally high ability managers are more likely to report lower violation of financial reporting standards and lower discretionary accruals, in other words, higher managerial ability in top executives always accompany with lower earnings management. This finding suggests that in the listed firms of China, earnings quality of these public firms could be highly related with top executives' managerial ability.

\section{Acknowledgements}

Many thanks for the help of CSMAR company to supply the original data to me. Thanks for the comments from my colleagues in Shanghai University.

\section{References}

Anderson, K., \& T. Yohn. (2002). The Effect of 10 - K Restatements on Firm Value, Information Asymmetries, and Investors' Reliance on Earnings. Working paper, Georgetown University.

Bamber, L., J. Jiang, \& I. Wang. (2010). What's My Style? The Influence of Top Managers on Voluntary Corporate Financial Disclosure. The Accounting Review, 85(4), 1131-1162. http://dx.doi.org/10.2308/accr.2010.85.4.1131 
Bertrand, M., \& A. Schoar. (2003). Managing With Style: The Effect of Managers on Firm Policies. The Quarterly Journal of Economics, CXVIII(4), 1169-1208. http://dx.doi.org/10.1162/003355303322552775

Brochet, F., L. Faurel, \& S. Mcvay. (2011). Manager-Specific Effects on Earnings Guidance: An Analysis of Top Executive Turnovers. Journal of Accounting Research, 49(5), 1123-1162.

Cooper, W, L.Seiford, \& K. Tone. (2000). Data envelopment analysis: A comprehensive text with models, applications, references and DEA-Solver software. Kluwer Academic Publishers.

Dechow Patricia M., \& Sloan Richard G. (1995). Detecting Earnings Management. Accounting Review, 70(2), 193-225.

Dechow, M., \& I. Dichev. (2002). The quality of accruals and earnings: The role of accrual estimation errors. The Accounting Review, 77(4), 35-59. http://dx.doi.org/10.2308/accr.2002.77.s-1.35

Dechow, M., A. Hutton, J. Kim, \& R. Sloan. (2012). Detecting Earnings Management: A New Approach. Journal of Accounting Research, 50(2), 275-334. http://dx.doi.org/10.1111/j.1475-679X.2012.00449.x

Dechow, P., W. Ge, \& C. Schrand. (2010). Understanding earnings quality: A review of the proxies, their determinants and their consequences. Journal of Accounting and Economics, 50, 344-401.

Demerjian, P., B. Lev, \& S. Mcvay. (2012). Quantifying managerial ability: A new measure and valididty tests. Management Science, 58(7), 1229-1248. http://dx.doi.org/10.1287/mnsc.1110.1487

Demerjian, P. R., B. Lev, M. F. Lewis, \& S. E. Mcvay. (2013). Managerial Ability and Earnings Quality. The Accounting Review, 88(2), 463-498. http://dx.doi.org/10.2308/accr-50318

Ecker, F. J.Francis, P.Olsson, \& K. Schipper. (2011). Peer firm selection for discretionary accruals models. Working paper, Duke University.

Finkelstein, S., \& D. Hambrick. (1996). Strategic Leadership: Top Executives and Their Effects on Organizations. St. Paul, MN: West Publishing Company.

Francis, J., A. Huang, S. Rajgopal, \& A. Zang. (2008). CEO reputation and earnings quality. Contemporary Accounting Research, 25(1), 109-147. http://dx.doi.org/10.1506/car.25.1.4

Francis, J., R. LaFond, P. Olsson, \& K. Schipper. (2004). Costs of equity and earnings attributes. The Accounting Review, 79(4), 967-1010. http://dx.doi.org/10.2308/accr.2004.79.4.967

Francis, J., R. LaFond, P. Olsson, \& K. Schipper. (2005). The market pricing of accruals quality. Journal of Accounting and Economics, 39(2), 295-327. http://dx.doi.org/10.1016/j.jacceco.2004.06.003

Ge, W., D. Matsumoto, \& J. Zhang. (2011). Do CFOs Have Style? An Empirical Investigation of the Effect of Individual CFOs on Accounting Practices. Contemporary Accounting Research, 28(4), 1141-1179.

Hambrick, D. (2007). Upper Echelons Theory: An Update. The Academy of Management Review, 32(2), 334 -343.

Hambrick, D., \& P. Mason. (1984). Upper Echelons: The Organization as a Reflection of Its Top Managers. The Academy of Management Review, 9(2), 193-206.

Hirshleifer, D., A. Low, \& S. Teoh. (2012). Are Overconfident CEOs Better Innovators? The Journal of Finance, LXVII(4), 1457-1498. http://dx.doi.org/10.1111/j.1540-6261.2012.01753.x

Jones J.J. (1991). Earnings Management During Import Relief Investigations. Journal of Accounting Research, 29(2), 193-228. http://dx.doi.org/10.2307/2491047

Lu, JianQiao. (1999). Empirical Research in Earnings Management of Chinese Loss listed Companies. Accounting Research (China), (9), 25-35.

Malmendier, U., \& G. Tate. (2009). Superstar CEOs. The Quarterly Journal of Economics, 124(4), 1593-1638

McNichols, M., \& P. Wilson. (1988). Evidence of earnings management from the provision for bad debts. Journal of Accounting research, 26(Supplement), 1-31. http://dx.doi.org/10.2307/2491176

Richardson, S., R. Sloan, M. Soliman, \& I. Tuna. (2005). Accrual reliability, earnings persistence and stock prices. Journal of Accounting and Economics, 39(3), 437-485. http://dx.doi.org/10.1016/j.jacceco.2005.04.005

\section{Notes}

Note 1. In their paper, press coverage is used to proxy for CEO reputation and various accrual measures are applied to proxy for earnings quality.

Note 2. DEAP version 2.1 is to calculate for cost efficiencies and for Malmquist TFP Indices. The DEAP program can be downloaded in the website: http://www.uq.edu.au/economics/cepa/deap.php.

Note 3. Unlike the prior research by Demerjian et al (2013), market share and business segment sectors are not included in the input variables because these variables cannot be found in the CSMAR database. 